\title{
Effect of INM on Vegetative Growth, Flowering and Fruiting of Andrographis Paniculata
}

\author{
Sushma Mishra*, Aruna Jain \\ Department of Botany, Sarojini Naidu Govt. Girls P.G (Autonomous) College Shivaji Nager, Bhopal \\ *Corresponding Author:mishrasushma21@gmail.com
}

Copyright (C) 2014 Horizon Research Publishing All rights reserved.

\begin{abstract}
An experiment was conducted to find out the effect of INM on vegetative growth, flowering and fruiting of Andrographis paniculata. The experiment was followed in a randomized block design with 8 treatments. The different treatments were $T_{1^{-}}$no treatment, $T_{2^{-}}$ vermicompost, $T_{3}$-biofertilizers, $T_{4}$-chemical fertilizers, $T_{5^{-}}$ biofertilizers + vermicompost, $\mathrm{T}_{6^{-}}$biofertilizers + chemical fertilizers, $\mathrm{T}_{7^{-}}$chemical fertilizers + vermicompost, $\mathrm{T}_{8^{-}}$ biofertilizers + chemical fertilizers + vermicompost. The results indicated that maximum growth i.e. plant height, number of branches, number of leaves, leaf length and breadth, leaf area, land area occupied by per plant and leaf area index, number of flowers and fruits of $A$. paniculata was found in $T_{8}$ plot treatment compare to other plots. From the analysis of result it has concluded that integrated use of biofertilizers, chemical fertilizers and vermicompost treatments significantly increased growth parameters of $A$. paniculata.
\end{abstract}

Keywords Biofertilizers, Chemical Fertilizers, Vermicompost, INM, Andrographis paniculata

\section{Introduction}

Medicinal plants offer alternative remedies with tremendous opportunities. Most of medicinal plants, even today are known to grow widely and naturally. Unfortunately, many of these plants are threatened by the hazard of extinction. Not surprisingly, wild plants species used for medicinal purposes are receiving ever increasing attention from the scientific community and commercial enterprises. It is necessary to initiate systematic cultivation of medicinal plants in order to conserve biodiversity and protect endangered species.

Agriculture has the greatest environmental impact of all types of economic activity, mainly because it is so land-intensive. Today, little undeveloped arable land remains on Earth. A wide variety of factors hinders the cultivation of new land, including low soil quality, arid climate, lack of infrastructure and environmental restrictions.
The application of an integrated plant nutrient supply system is becoming popular as it is scientifically sound and assures sustainable development in agriculture. The use of judicious combination of organic and inorganic fertilizer source is essential not only to maintain soil health but also sustain productivity (Malewar et al., 1998).

A.paniculata has been used for centuries in Asia for the treatment of various ailments. It is one among the prioritized medicinal plant in India. The plant is known as ' King of bitters'. it is one of the bitterest, annual herbaceous plant. The plant contains a number of diterpenoid. Andrographolide (the diterpenoid lactones) is the main bitter principle found in high concentrations in the leaves of Kalmegh (Tang.W. et al., 1992). Andrographolide showed anticancer activity on diverse cancer cells representing different types of human cancers (Kumar R.A. et al., 2004). Calabrese, et al., (2000) has conducted a trial on HIV patients and found effective. ). Beyond this effects it is useful as an anti inflammatory (Shen Y.C. et al., 2002), antiviral (Wiart C. et al., 2005), antimalarial (Mishra P. et al., 1992 and Rahman, et al., 1999) hepatoprotective (Handa S.S. et al., $1990)$ etc. Looking at the utility and importance of A.paniculata, it is need to make better by developing systematic agro-techniques. To achieve maximum growth, we should apply biofertilizers, chemical fertilizers and organic manures i.e. vermicompost. For sustainability, it's important to incorporate bio-organisms and organic matter into the soil. The present investigation was, therefore, carried out to see the effect of INM on vegetative growth, flowering and fruiting of Andrographis paniculata.

\section{Material and Method}

The field experiment was conducted at Sarojini Naidu Govt. Girls P.G. (Autonomous) college, Bhopal, Madhya Pradesh. The experiment was conducted in a randomized block design (RBD) with 8 treatments and 3 replicas of each, using chemical fertilizers (NPK), vemicompost, and bio fertilizers (Azotobacter, phosphate solubilizing bacteria) in different combinations including one control treatment. The treatments were $\mathrm{T}_{1}-$ control (no treatment), $\mathrm{T}_{2}$ 
-Vermicompost 5t ha ${ }^{-1}, \mathrm{~T}_{3}$ - Biofertlizers (250g Azotobacter $\left.\mathrm{ha}^{-1}+250 \mathrm{~g}^{\mathrm{PSB} \mathrm{h}} \mathrm{ha}^{-1}\right), \mathrm{T}_{4}$ - Chemical fertilizers ( 60:30:30kg NPK ha $\left.{ }^{-1}\right), \mathrm{T}_{5}-\mathrm{BF}+\mathrm{VC}(125 \mathrm{~g}$ Azotobacter $+125 \mathrm{~g}$ PSB + 5 t vermicompost ha $\left.{ }^{-1}\right), \mathrm{T}_{6}-\mathrm{BF}+\mathrm{CF}[125 \mathrm{~g}$ Azotobacter + $125 \mathrm{~g}$ PSB $+50 \%$ NPK $\left.(\mathrm{RDF}) \mathrm{ha}^{-1}\right], \mathrm{T}_{7}-\mathrm{CF}+\mathrm{VC}(50 \%$ $\mathrm{NPK}+5 \mathrm{t}$ vermicompost $\left.\mathrm{ha}^{-1}\right)$ and $\mathrm{T}_{8}-\mathrm{BF}+\mathrm{CF}+\mathrm{VC}[250 \mathrm{~g}$ bio fertilizers ( $125 \mathrm{~g}$ Azotobacter $+125 \mathrm{~g}$ PSB $)+50 \%$ NPK (RDF as 30:15:15 $\mathrm{kg}$ per ha $^{-1}$ ) $+5 \mathrm{t} \mathrm{VC}$.

For recording various biometric observations, five plants were randomly selected for sampling, and tagged for recording the growth parameters. After sowing, 30 DAS plant height, number of branches, number of leaves, leaf length and breadth, leaf area, land area occupied by per plant and leaf area index, no. of flowers and fruits were recorded.
Leaf area was calculated by the formula:-

Leaf Area $=$ leaf length $\times$ leaf breadth

Leaf area index was worked out by the formula (Sesak et al., 1971).

\section{Leaf area of per plant \\ LAI \\ Land area occupied by per plant.}

The results were statistically analyzed by using SPSS software, version 20, 2011.

\section{Result and Discussion}

Table 1. Effect of different nutrient sources on morphological parts of

A. paniculata at vegetative stage.

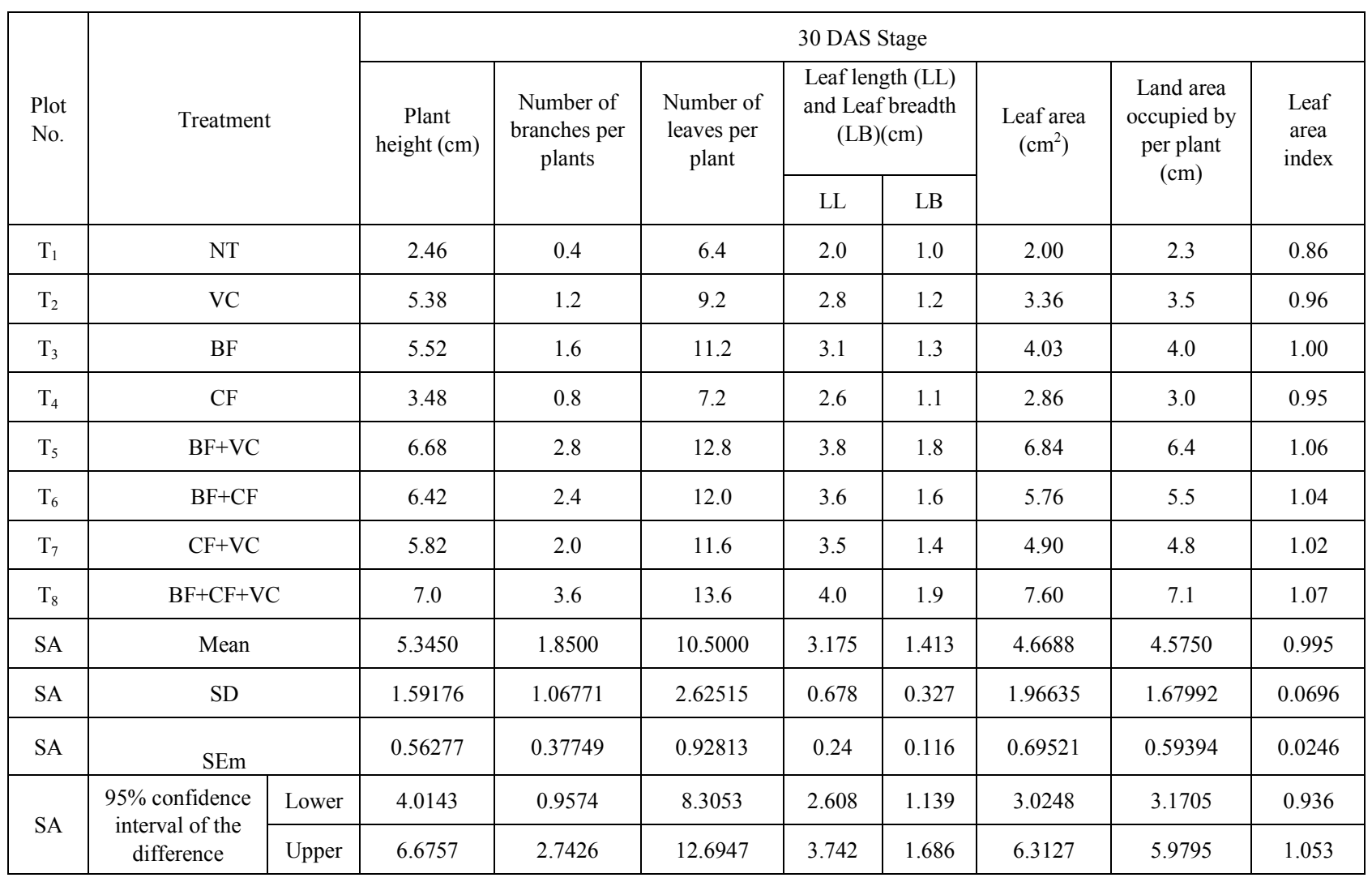


Table 2. Effect of different nutrient sources on morphological parts of A. paniculata at Harvesting stage.

\begin{tabular}{|c|c|c|c|c|c|c|c|c|c|c|}
\hline \multirow{3}{*}{$\begin{array}{l}\text { Plot } \\
\text { No. }\end{array}$} & \multirow{3}{*}{\multicolumn{2}{|c|}{ Treatment }} & \multicolumn{8}{|c|}{135 DAS } \\
\hline & & & \multirow{2}{*}{$\begin{array}{l}\text { Plant } \\
\text { height } \\
(\mathrm{cm})\end{array}$} & \multirow{2}{*}{$\begin{array}{c}\text { Number of } \\
\text { branches per } \\
\text { plants }\end{array}$} & \multirow{2}{*}{$\begin{array}{l}\text { Number of } \\
\text { leaves per } \\
\text { plant }\end{array}$} & \multicolumn{2}{|c|}{$\begin{array}{l}\text { Leaf length (LL) } \\
\text { and Leaf breadth } \\
(\mathrm{LB})(\mathrm{cm})\end{array}$} & \multirow{2}{*}{$\begin{array}{l}\text { Leaf area } \\
\left(\mathrm{cm}^{2}\right)\end{array}$} & \multirow{2}{*}{$\begin{array}{l}\text { Land area } \\
\text { occupied by } \\
\text { per plant } \\
(\mathrm{cm})\end{array}$} & \multirow{2}{*}{$\begin{array}{c}\text { Leaf area } \\
\text { index }\end{array}$} \\
\hline & & & & & & LL & LB & & & \\
\hline $\mathrm{T}_{2}$ & \multicolumn{2}{|l|}{$\mathrm{VC}$} & 42.26 & 47.6 & 84.4 & 8.3 & 2.1 & 17.43 & 15.3 & 1.13 \\
\hline $\mathrm{T}_{3}$ & \multicolumn{2}{|l|}{$\mathrm{BF}$} & 45.22 & 50.4 & 86.0 & 8.5 & 2.2 & 18.70 & 16.4 & 1.14 \\
\hline $\mathrm{T}_{4}$ & \multicolumn{2}{|l|}{$\mathrm{CF}$} & 38.6 & 42.0 & 80.0 & 6.1 & 1.9 & 11.59 & 10.4 & 1.11 \\
\hline $\mathrm{T}_{5}$ & \multicolumn{2}{|l|}{$\mathrm{BF}+\mathrm{VC}$} & 48.34 & 62.0 & 91.2 & 9.6 & 2.6 & 24.96 & 20.1 & 1.24 \\
\hline $\mathrm{T}_{6}$ & \multicolumn{2}{|l|}{$\mathrm{BF}+\mathrm{CF}$} & 48.28 & 60.0 & 90.4 & 9.3 & 2.4 & 22.32 & 18.1 & 1.23 \\
\hline $\mathrm{T}_{7}$ & \multicolumn{2}{|l|}{$\mathrm{CF}+\mathrm{VC}$} & 45.5 & 58.4 & 89.6 & 9.1 & 2.3 & 20.93 & 17.6 & 1.18 \\
\hline $\mathrm{T}_{8}$ & \multicolumn{2}{|c|}{$\mathrm{BF}+\mathrm{CF}+\mathrm{VC}$} & 51.64 & 66.0 & 91.6 & 9.8 & 2.7 & 26.46 & 20.3 & 1.30 \\
\hline $\mathrm{SA}$ & \multicolumn{2}{|l|}{ Mean } & 43.2625 & 53.0500 & 86.4500 & 8.138 & 2.238 & 18.7338 & 15.6250 & 1.1788 \\
\hline SA & \multicolumn{2}{|l|}{$\mathrm{SD}$} & 7.94450 & 10.07160 & 5.14670 & 1.907 & 0.338 & 6.49755 & 4.74786 & 0.0716 \\
\hline $\mathrm{SA}$ & \multicolumn{2}{|l|}{ SEm } & 2.80881 & 3.56085 & 1.81963 & 0.674 & 0.119 & 2.29723 & 1.67862 & 0.0253 \\
\hline \multirow{2}{*}{ SA } & \multirow{2}{*}{$\begin{array}{l}95 \% \text { confidence } \\
\text { interval of the } \\
\text { difference }\end{array}$} & Lower & 36.6207 & 44.6299 & 82.1472 & 6.543 & 1.955 & 13.3017 & 11.6557 & 1.118 \\
\hline & & Upper & 49.9043 & 61.4701 & 90.7528 & 9.732 & 2.52 & 24.1658 & 19.5943 & 1.238 \\
\hline
\end{tabular}

Table 3. Effect of different nutrient sources on reproductive part of

Andrographis paniculata at vegetative and harvesting stage.

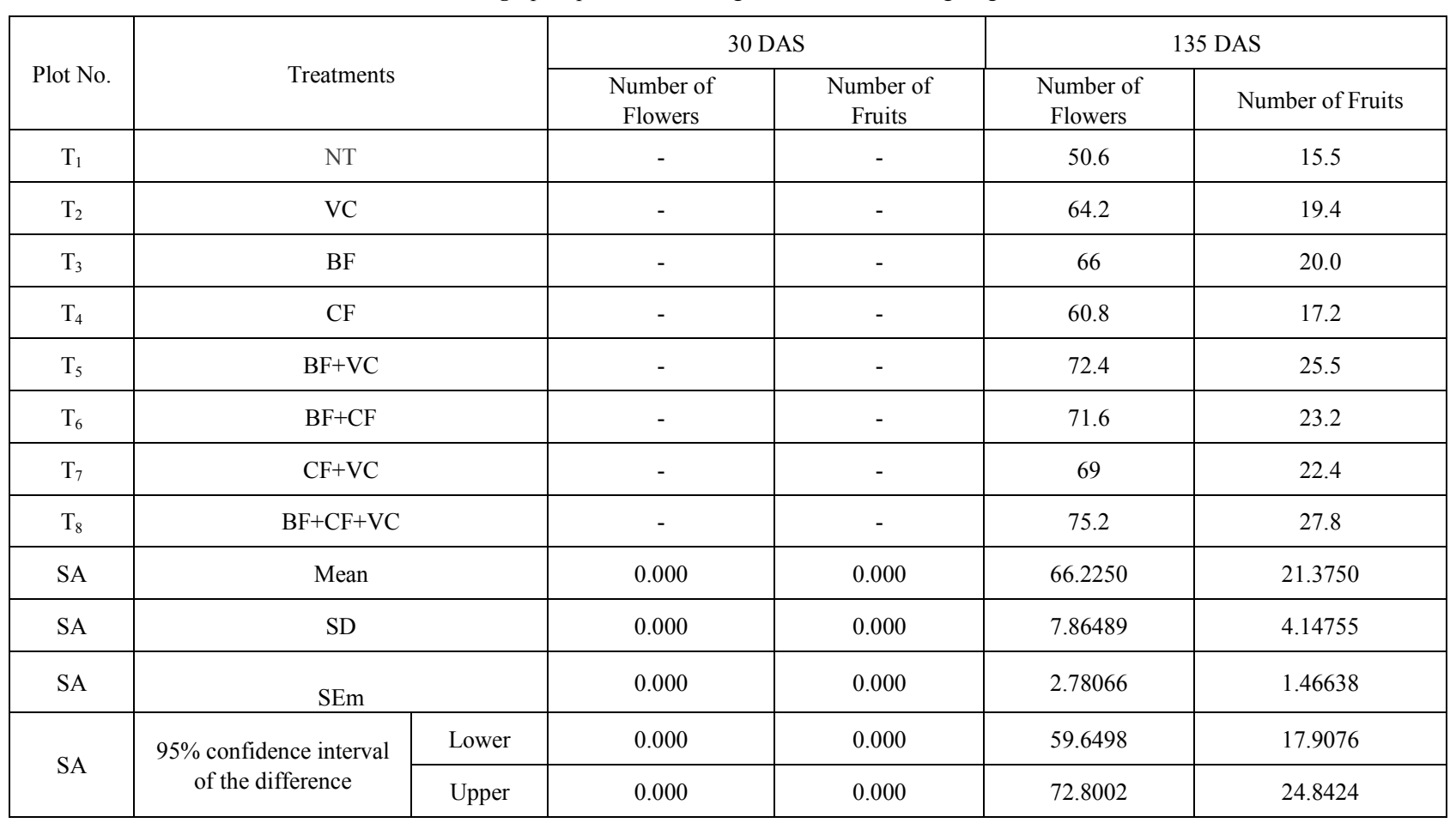

Abbreviations:- NT- No Treatment, BF-Biofertilizers, CF- Chemical Fertilizers, LL-Leaf Length, LB-Leaf Breadth, VC- Vermicompost, SD- Standard Deviation, SEm- Standard Error mean, SA-Statistical Analysis, INM- Integrated Nutrient Management, N-nitrogen, P-phosphorus, K- Potassium, PSBphosphate solubilising bacteria. 
In the present research, it was found that, at 30 DAS, maximum plant height $(7.0 \mathrm{~cm})$, number of branches (3.6), number of leaves (13.6), leaf length and breadth $(4.0 \mathrm{~cm} \mathrm{LL}$, $1.9 \mathrm{~cm} \mathrm{LB})$, leaf area $\left(7.60 \mathrm{~cm}^{2}\right)$, land area occupied by per plant $(7.1 \mathrm{~cm})$ and leaf area index (1.07) was recorded in $T_{8}$ plot followed by $\mathrm{T}_{5}$ plot treatment (Table 1) whereas no flowering was seen (Table 3). Similarly, at 135 DAS Maximum plant height $(51.64 \mathrm{~cm})$, number of branches (66.0), number of leaves (91.6), leaf length and breadth $(9.8 \mathrm{~cm} \mathrm{LL}, 2.7 \mathrm{~cm} \mathrm{LB})$, leaf area $\left(26.46 \mathrm{~cm}^{2}\right)$, land area occupied by per plant $(20.3 \mathrm{~cm})$ and leaf area index $(1.30)$ was recorded in $T_{8}$ plot (Table 2). Maximum number of flowers (75.2) and fruits (27.8) were also recorded in $\mathrm{T}_{8}$ plot (Table 3 ) follower by $\mathrm{T}_{5}$ plot treatment.

The present study reveals that maximum growth of morphological and reproductive parts of plants increases in $\mathrm{T}_{8}$ plot compare to other plots. Same results has been already reported by Tara DW and MS Fatima., 2008 in Cowpea; Sarhan et al.,2011 in summer Squash; Shanthi et al., 2012 in Sunflower; Meenakumari and Shekher, 2012 in Tomato; Rubee Lata et al., 2013 in strawberry; Anita Mohanty et al., 2013 in Marigold. Good soil fertility management ensures adequate nutrient availability to plant and improve their growth. Only inorganic fertilizers can't sustain plant growth of land under modern farming. Likewise, nutrient supply through organic manures or biofertilizers can hardly fulfil the need of a plant. From the above results it may be stated that the use of bio-fertilizers, chemical fertilizers along with vermicompost in integrated manner is beneficial in improving the growth of Andrographis paniculata.

\section{REFERENCES}

[1] Anita Mohanty, C. R. Mohanty and P. K. Mohapatra.(2013). Studies on the Response of Integrated Nutrient Management on Growth and Yield of Marigold (Tagetes erecta L.). Research Journal of Agricultural Sciences. 4(3): 383-385.

[2] Calabrese C., S.H. Berman, J.G. Babish, X. M.A., L. Shinto, M. Dorr, K. Wells, C.A. Werner and L.J. Standish (2000). A phase I trial of andrographolide in HIV positive patients and normal volunteers. Phytothery. Res., 14(5): 333-338.

[3] Kumar R.A., K. Sridevi, N.V. Kumar, S. Nanduri and S. Rajagopal (2004). Anticancer and immunostimulatory compounds from Andrographis paniculata. J. Etanopharma., 92(2-3): 291-295.

[4] Handa S.S. and A. Sharma (1990). Hepatoprotective activity of andrographolide from Andrographis paniculata against carbon tetra chloride. Indian J. Med. Res., 92: 276-283.

[5] Meenakumari T. and M. Shekher. (2012). Vermicompost and other fertilizers effect on growth, yield and nutritional status of Tomato (Lycopersicon esculentum) plant. World Research Journal of Agricultural Biotechnology. Vol. (1): pp. 14-16.

[6] Mishra P., N.L. Pal, P.Y., Guru,J.C., Katiyar, V. Shrivastava and J.C. Tandon (1992). Antimalarial activity of Andrographis paniculata (Kalmegh) against Plasmodium berghei NK 65 in Mastomys natalensis. International Journal of Pharmacognosy. 30:263-274.

[7] Malewar, G. U; Syed Ismail and Rudraksha, G.B. (1998): Integrated Nitrogen management in chilli (Capsicum annum L.). Bull. Indian Inst. Soil Sci., 2 :156-163.

[8] Rahman N.N.N.A., T. Furuta, S. Kajima, K. Takane and M.A. Mohd (1999). Antimalarial activity of extracts of Malaysian medicinal plants. J. Ethnopharmacol. 64: 249-254.

[9] Rubee Lata*, Deepa H. Dwivedi, R.B. Ram, M.L. Meena and Mukesh Babu (2013). Impact of Integrated Nutrient Management on growth parameters of Strwberry CV. Chanderunder sub tropical condition of Luckhnow. International Journal of Advanced Biological Research, VOL. 3(3): 418-421.

[10] Sarhan T.Z., G.H. Mohammed and J.A. Teli (2011). Effect of bio and organic fertilizers on growth, yield and fruit quality of summer Squesh. Sarhad J. Agric. 27(3): 377-383.

[11] Sesak Z., J. Catasky and P.G. Jarris (1971). Plant photosynthetic production manual of methods, Edition, Junk W.N.V., Publication. The Hague, pp. 348-381.

[12] Shanthi J., V. Santhi, S. Ramya and R. Balagurunathan. (2012). Effect of Azotobacter spp. and phosphobacter bioinoculants on the growth of Sunflower (Helianthus annus L.). Word Journal of Agricultural Research Sciences . 8(2): 218-222.

[13] Shen Y.C., C.F. Chen and W.F. Chiou (2002). Andrographolide prevents oxygen radical production by human neutrophils: possible mechanism(s) involved in its anti-inflammatory effect. Br. J. Pharmacol, 135: 399-406.

[14] Statistical analysis. (2011).SPSS software, version 20.

[15] Tang W. and G. Eisenbrandt (1992). Drugs of plant origin : chemistry and use in traditional and modern medicine. Pharmacology. New York.

[16] Tara D.W. and M.S. Fatima. (2008). Effect of organic and inorganic fertilizers on the vegetative and reproductive parts of some selected varieties of Cowpea (Vigna unguiculata). African Journal of Agriculture. Vol. 4. No. 2. 